\title{
Recurrent Selection with Glufosinate at Low Rates Reduces the Susceptibility of a Lolium perenne ssp. multiflorum Population to Glufosinate
}

\author{
Maor Matzrafi $^{1,2, * \mathbb{D}}$, Sarah Morran ${ }^{1,3} \mathbb{D}$ and Marie Jasieniuk ${ }^{1}$ \\ 1 Department of Plant Sciences, University of California-Davis, Davis, CA 95616, USA; \\ sarah.morran@colostate.edu (S.M.); mjasien@ucdavis.edu (M.J.) \\ 2 Department of Plant Pathology and Weed Research, Agricultural Research Organization, \\ Newe Ya'ar Research Center, Ramat-Yishay 30095, Israel \\ 3 Department of Bioagricultural Sciences and Pest Management, 1177 Campus Delivery, \\ Colorado State University, Fort Collins, CO 80523, USA \\ * Correspondence: maorm@volcani.agri.gov.il
}

Received: 6 July 2020; Accepted: 27 August 2020; Published: 31 August 2020

\begin{abstract}
Repeated applications of herbicides at the labelled rates have often resulted in the selection and evolution of herbicide-resistant weeds capable of surviving the labelled and higher rates in subsequent generations. However, the evolutionary outcomes of recurrent herbicide selection at low rates are far less understood. In this study of a herbicide-susceptible population of Lolium perenne ssp. multiflorum, we assessed the potential for low glufosinate rates to select for reduced susceptibility to the herbicide, and cross-resistance to herbicides with other modes of action. Reduced susceptibility to glufosinate was detected in progeny in comparison with the parental population following three rounds of selection at low glufosinate rates. Differences were mainly observed at the $0.5 \mathrm{X}, 0.75 \mathrm{X}$, and $1 \mathrm{X}$ rates. Comparing the parental susceptible population and progeny from the second and third selection cycle, the percentage of surviving plants increased to values of $\mathrm{LD}_{50}(1.31$ and 1.16, respectively) and $\mathrm{LD}_{90}$ (1.36 and 1.26, respectively). When treated with three alternative herbicides (glyphosate, paraquat, and sethoxydim), no plants of either the parental or successive progeny populations survived treatment with $0.75 \mathrm{X}$ or higher rates of these herbicides. The results of this study provide clear evidence that reduced susceptibility to glufosinate can evolve in weed populations following repeated applications of glufosinate at low herbicide rates. However, the magnitude of increases in resistance levels over three generations of recurrent low-rate glufosinate selection observed is relatively low compared with higher levels of resistance observed in response to low-rate selection with other herbicides (three fold and more).
\end{abstract}

Keywords: low-dose selection; herbicide resistance; resistance evolution; Italian ryegrass; California

\section{Introduction}

Weeds are the major pests limiting crop production in agricultural systems [1]. Treatment with herbicides is by far the most effective method of controlling weeds, although repeated applications of herbicides select for, and can result in, the evolution of herbicide resistance [2,3]. When applied at labelled field rates, herbicides have often selectively favored individuals possessing major resistance alleles and target-site resistance (TSR) that spread rapidly within and among weed populations [2,3]. However, the evolutionary outcomes of recurrent herbicide selection at rates lower than the labelled rates are far less understood. It has been suggested that repeated applications of herbicides at lower than labelled rates selects for polygenic herbicide resistance in weeds [4]. Consequently, each subsequent generation of selection is predicted to result in a slow shift of the entire population towards resistance. 
For instance, recurrent selection with low rates of dicamba [5] and glyphosate [6] only resulted in 2.15to 3-fold lower susceptibility of Amaranthus palmeri to these herbicides over three to four generations in comparison to the parental populations. In contrast, however, three generations of recurrent selection with low rates of diclofop-methyl resulted in a high level (56-fold) of resistance in Lolium perenne ssp. rigidum [7].

Recurrent selection at low herbicide rates has sometimes also resulted in the selection of progeny with cross-resistance to other herbicides. For instance, repeated applications of pyroxasulfone at low rates resulted in the selection of a L. perenne ssp. rigidum population that was resistant to pyroxasulfone and cross-resistant to chlorsulfuron, diclofop-methyl, and S-metolachlor [8]. In Avena fatua, repeated applications of diclofop-methyl, an ACCase (acetyl CoA carboxylase)-inhibiting herbicide, at low rates for three consecutive generations resulted in the selection of progeny populations with reduced susceptibility to diclofop-methyl and cross-resistance to ALS-inhibiting herbicides [9].

L. perenne ssp. multiflorum (Italian ryegrass) is one of the major weed species in orchards, vineyards, field crops, and fallow fields of California [10,11]. Extensive herbicide use has exerted strong selection that has resulted in the evolution of herbicide resistance in many populations of this weed species in California [11-15]. Resistance to glyphosate [11,13,16], paraquat, and the ACCase inhibitor, sethoxydim [14], as well as multiple herbicide resistance to these three herbicides plus acetolactate synthase (ALS) inhibitors [14,15] have been confirmed in populations across the agricultural landscape of northern California. Consequently, the management of herbicide-resistant L. perenne ssp. multiflorum has become a major challenge in California annual and perennial cropping systems.

Glufosinate is an alternative non-selective post-emergence herbicide that can still be used to control herbicide-susceptible and most herbicide-resistant L. perenne ssp. multiflorum in California, as only two populations with glufosinate resistance have been documented to date [13]. Both are populations with low resistance levels (1.6-2 fold) compared to the standard susceptible population. Worldwide, six additional cases of glufosinate resistance have been reported in Lolium species [17]. In Oregon, both target site and non-target site mechanisms were suggested as endowing resistance to glufosinate in L. perenne ssp. multiflorum populations [18,19].

The relatively high cost of glufosinate, as well as the increasing abundance of weeds resistant to alternative herbicides, may drive farmers to apply more glufosinate, but at reduced rates. This, among other drivers such as herbicide applications at non-optimal weed size, inappropriate weather conditions, and insufficient spray coverage may result in sublethal rate herbicide selection. Thus, there is a need to assess the potential for recurrent selection with glufosinate at low rates in L. perenne ssp. multiflorum, the weed species with a high propensity to evolve resistance to herbicides with different modes of action.

Hence, the objectives of the present study were (1) to evaluate the potential for low glufosinate rates to select for reduced susceptibility to the herbicide, and (2) to determine if selected populations are cross-resistant to herbicides with other modes of action that are commonly used to control L. perenne ssp. multiflorum in orchards and vineyards of California.

\section{Materials and Methods}

\subsection{Plant Material}

Seeds of a previously characterized herbicide-susceptible population of L. perenne ssp. multiflorum from a vineyard in Sonoma County, California $[14,15]$ constituted the parental population $\left(\mathrm{P}_{0}\right)$ for this study. Seeds were germinated on moistened filter paper in Petri plates with $1 \% v / v$ Captan 80 WDG (Agri Star, Ankeny, IA, USA) and incubated at ambient temperature under a 12-h photoperiod provided by fluorescent lights $\left(160 \mu \mathrm{mol} \cdot \mathrm{m}^{2} \cdot \mathrm{s}^{-1}\right)$. Seedlings at the one- to two-leaf stage were transplanted into plastic pots $(5 \mathrm{~cm}$ height $\times 4.5 \mathrm{~cm}$ diameter) filled with UCD Ron's soil mix (1:1:1:3 sand/compost/peat/dolomite). Pots were maintained in a growth chamber (model PGV 36; Conviron 
Ltd., Winnipeg, $\mathrm{MB}$, Canada) under $25 / 19+3{ }^{\circ} \mathrm{C}$ (day/night) temperature and 12-h photoperiod using high pressure sodium lamps $\left(600 \mu \mathrm{mol} \cdot \mathrm{m}^{2} \cdot \mathrm{s}^{-1}\right)$.

\subsection{Recurrent Selection with Glufosinate at Low Rates}

Six hundred $\mathrm{P}_{0}$ seedlings at the three- to four-leaf stage ( $8-10 \mathrm{~cm}$ tall) were divided into three sets of 200 seedlings. Each set of $200 \mathrm{P}_{0}$ seedlings was treated with glufosinate (Rely $280^{\circledR}$, Bayer CropScience, Research Triangle Park, NC, USA) at one of three rates $\left(123,246\right.$, or 492 g.ai.ha ${ }^{-1}$ ), equivalent to $0.125 \mathrm{X}, 0.25 \mathrm{X}$, and $0.5 \mathrm{X}$ of the labelled field rate $\left(984 \mathrm{~g} \cdot \mathrm{ai} \cdot \mathrm{ha}^{-1}\right)$. Glufosinate was applied using an automated track sprayer equipped with a 8001E flat-fan nozzle (TeeJet Technologies, Springfield, IL,

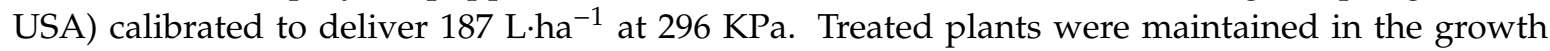
chamber under the conditions described above. The number of surviving plants was recorded 21 days after treatment (DAT). Glufosinate at the rate of $492 \mathrm{~g} \cdot \mathrm{ai} \cdot \mathrm{ha}^{-1}$ resulted in highest plant mortality $(76.5 \%)$ among the rates used. All 47 surviving plants were transplanted into larger round plastic pots $(2.37 \mathrm{~L})$ filled with commercial potting mix (LC1, Sun Gro Horticulture, Seba Beach, AB, Canada), grown to maturity under the conditions described above, and allowed to cross-pollinate. Mature seeds that were collected from these plants, designated the $\mathrm{P}_{1}$ generation, were air-dried at room temperature and stored at $4{ }^{\circ} \mathrm{C}$ for four to six weeks to overcome dormancy and maximize germination for a subsequent round of selection.

For the second round of selection, $\mathrm{P}_{1}$ seeds were germinated and seedlings transplanted into pots and grown to the three- to four-leaf stage, as described above. For this selection round, $900 \mathrm{P}_{1}$ seedlings were divided into three sets of 300 seedlings. Each set of $300 \mathrm{P}_{1}$ plants was treated with glufosinate at one of three slightly higher rates of glufosinate $(0.5 \mathrm{X}, 0.75 \mathrm{X}$, and $1 \mathrm{X})$ than in the first round of selection. Approximately 50 surviving plants were selected from the $738 \mathrm{~g} \cdot \mathrm{ai} \cdot \mathrm{ha}^{-1}$ rate $(0.75 \mathrm{X})$, which resulted in $79 \%$ plant mortality, and transplanted into larger pots, grown to maturity, and allowed to cross-pollinate. Mature seeds were collected, designated the $\mathrm{P}_{2}$ generation, and stored for four to six weeks to overcome dormancy. A similar approach was taken for an additional round of selection with glufosinate at three higher rates, equivalent to $0.75 \mathrm{X}, 1 \mathrm{X}$, and 1.25X the labelled field rate, to produce the $\mathrm{P}_{3}$ generation of seeds.

\subsection{Dose-Response of the Parental and Selected Populations to Glufosinate}

To compare the response of the parental population $\left(\mathrm{P}_{0}\right)$ and the selected progeny populations $\left(\mathrm{P}_{1}\right.$, $\left.\mathrm{P}_{2}, \mathrm{P}_{3}\right)$ to glufosinate, seedlings at the 3- to 4-leaf stage $(8-10 \mathrm{~cm})$ from each generation were treated with glufosinate at seven rates $(0.125 \mathrm{X}, 0.25 \mathrm{X}, 0.5 \mathrm{X}, 0.75 \mathrm{X}, 1 \mathrm{X}, 2 \mathrm{X}$, and $4 \mathrm{X})$. Following treatment, plants were kept for 21days in the growth chamber under the environmental conditions described earlier. The experiment was conducted in a completely randomized design (CRD) with 10-12 replications of individual plants from each generation per treatment. The whole experiment was repeated twice. Plant survival was recorded 21 DAT.

\subsection{Cross-Resistance to Glyphosate, Paraquat, and Sethoxydim}

In an experimental design (CRD) similar to that described above for the glufosinate dose-response study, cross-resistance to other herbicides was assessed for the parental population $\left(\mathrm{P}_{0}\right)$ and for the three selected progeny populations $\left(\mathrm{P}_{1}, \mathrm{P}_{2}, \mathrm{P}_{3}\right)$. The experiment was conducted in a completely randomized design (CRD) with five replications of individual plants from each generation per treatment. The whole experiment was repeated twice. Seedlings at the 3- to 4-leaf stage $(8-10 \mathrm{~cm})$ from each generation were treated with seven rates $(0.125 \mathrm{X}, 0.25 \mathrm{X}, 0.5 \mathrm{X}, 0.75 \mathrm{X}, 1 \mathrm{X}, 2 \mathrm{X}$, and $4 \mathrm{X})$ of glyphosate (Roundup PowerMax ${ }^{\circledR}$, Monsanto. St. Louis, MO, USA; $1 \mathrm{X}=867 \mathrm{~g} \cdot$ ae $\cdot \mathrm{ha}^{-1}$ ), paraquat (Gramoxone SL 2.0 ${ }^{\circledR}$, Syngenta Crop Protection, Greensboro, NC, USA; $1 \mathrm{X}=560 \mathrm{~g} \cdot \mathrm{ai} \cdot \mathrm{ha}^{-1}$ ), and sethoxydim (Poast ${ }^{\circledR}$, BASF Corporation, Research Triangle Park, NC, USA; 1X $=515 \mathrm{~g} \cdot \mathrm{ai}^{\mathrm{h}} \mathrm{ha}^{-1}$ ). Crop oil concentrate (COC; Helena Chemical Company, Collierville, TN, USA) at $1 \% v / v$ and nonionic surfactant (NIS; Helena Chemical Company) at $0.25 \% v / v$ were added to spray solutions containing sethoxydim and 
paraquat, respectively. Treated plants were kept in a growth chamber under the environmental conditions described earlier and plant survival recorded 21 DAT.

\subsection{Statistical Analyses}

Plant survival and shoot biomass data were pooled over the two runs of each experiment due to nonsignificant differences between runs for all experiments (data not shown). For all herbicides, plant survival data from the dose-response experiments for the $\mathrm{P}_{0}, \mathrm{P}_{1}, \mathrm{P}_{2}$, and $\mathrm{P}_{3}$ populations were fit to a binomial two-parameter log-logistic model using the drc package of $\mathrm{R}$ version 3.5.1 [20] and the $\mathrm{LD}_{50}$ values (rate required for $50 \%$ plant mortality) and $\mathrm{LD}_{90}$ values (rate required for $90 \%$ plant mortality) estimated. RI, the resistance index, was calculated as a population's $\mathrm{LD}_{50}$ or $\mathrm{LD}_{90}$ divided by the value of the same parameter for the parental population, $\mathrm{P}_{0}$. SE values for RI were obtained using the drc package of $\mathrm{R}$ version 3.5.1 [20] calculated using the delta method.

To further assess cross-resistance of the $\mathrm{P}_{0}, \mathrm{P}_{1}, \mathrm{P}_{2}$, and $\mathrm{P}_{3}$ populations to glyphosate, paraquat, and sethoxydim, data on the percentage of fresh shoot weight reduction from the dose-response experiments were fit to a nonlinear sigmoidal logistic three-parameter model [21].

All data was visualized using SigmaPlot (ver. 13) software (Systat Software Inc., San Jose, CA, USA).

\section{Results and Discussion}

\subsection{Recurrent Selection with Glufosinate at Low Rates}

As expected, the percentage of $\mathrm{P}_{0}$ plants surviving treatment with glufosinate was inversely related to the herbicide rate, with $100 \%, 90.5 \%$, and $23.5 \%$ of plants surviving $0.125 \mathrm{X}, 0.25 \mathrm{X}$, and $0.5 \mathrm{X}$ times the labelled field rate of glufosinate, respectively, 21 DAT (Table 1). Repeated selection with glufosinate at low rates over three consecutive generations produced three successive populations $\left(\mathrm{P}_{1}\right.$, $\mathrm{P}_{2}$, and $\mathrm{P}_{3}$ ) of progeny with an increasing percentage of plants surviving treatment with glufosinate at a specific rate. Thus, whereas only $23.5 \%$ of $\mathrm{P}_{0}$ plants survived the $0.5 \mathrm{X}$ rate of glufosinate, a larger percentage $(71 \%)$ of $\mathrm{P}_{1}$ plants survived the same dose in the next generation (Table 1$)$. Similarly, only $21 \%$ and $5 \%$ of $\mathrm{P}_{1}$ plants, but $33 \%$ and $12 \%$ of $\mathrm{P}_{2}$ plants, survived the $0.75 \mathrm{X}$ and $1 \mathrm{X}$ rates of the herbicide, respectively, indicating that selection with glufosinate at low rates had reduced susceptibility to the herbicide, as assessed by the increasing proportions of survivors at each rate over generations.

Table 1. Percentage of L. perenne ssp. multiflorum plants surviving treatment with glufosinate at low (i.e., lower than the recommended labelled) rates.

\begin{tabular}{|c|c|c|c|}
\hline Population & 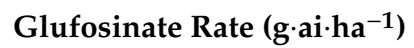 & Seedling Treated (n) & Survivors (\%) \\
\hline \multirow{3}{*}{ Parental $\left(\mathrm{P}_{0}\right)$} & $123(0.125 X)$ & 200 & 100 \\
\hline & $246(0.25 X)$ & 200 & 90.5 \\
\hline & $492(0.5 X)$ & 200 & 23.5 \\
\hline \multirow{3}{*}{$P_{1}$} & $492(0.5 X)$ & 300 & 71 \\
\hline & $738(0.75 X)$ & 300 & 21 \\
\hline & $984(1 X)$ & 300 & 5 \\
\hline \multirow{3}{*}{$\mathrm{P}_{2}$} & $738(0.75 X)$ & 300 & 33 \\
\hline & $984(1 X)$ & 300 & 12 \\
\hline & $1230(1.25 X)$ & 300 & 7 \\
\hline
\end{tabular}

Note: Bold text and grey highlighted boxes indicate the rates from which surviving plants were selected for subsequent recurrent selection. 


\subsection{Dose-Response of Parental and Selected Populations to Glufosinate and Other Herbicides}

Progeny populations $\mathrm{P}_{2}$ and $\mathrm{P}_{3}$ exhibited reduced susceptibility to glufosinate at rates ranging from the $0.5 \mathrm{X}$ to $1 \mathrm{X}$ the labelled field rate in comparison with the parental population $\left(\mathrm{P}_{0}\right)($ Figure 1$)$. $\mathrm{LD}_{50}$ and $\mathrm{LD}_{90}$ values for populations $\mathrm{P}_{2}$ (592.08 and $1117.58 \mathrm{~g} \cdot \mathrm{ai} / \mathrm{ae} \cdot \mathrm{ha}^{-1}$, respectively) and $\mathrm{P}_{3}(529.2$ and $1038.16 \mathrm{~g} \cdot \mathrm{ai} / \mathrm{ae} \cdot \mathrm{ha}^{-1}$, respectively) were higher in comparison with those of the $\mathrm{P}_{0}(452.39$ and $816.66 \mathrm{~g} \cdot \mathrm{ai} / \mathrm{ae} \cdot \mathrm{ha}^{-1}$, respectively) and $\mathrm{P}_{1}$ (429.95 and $888.82 \mathrm{~g} \cdot \mathrm{ai} / \mathrm{ae} \cdot \mathrm{ha}^{-1}$, respectively) populations (Table 2). The level of resistance, as measured by the resistance index (RI) calculated using LD $_{50}$ values and the parental population $\mathrm{P}_{0}$ as the susceptible standard, revealed RI values of $0.95,1.31$, and 1.16 for the $P_{1}, P_{2}$, and $P_{3}$ populations, respectively. Based on $L D_{90}$ values, $R I$ values were $1.08,1.36$, and 1.26 for the $\mathrm{P}_{1}, \mathrm{P}_{2}$, and $\mathrm{P}_{3}$ populations, respectively. Our results clearly show that glufosinate survival rate (LD $\mathrm{L}_{50}$ and $\mathrm{LD}_{90}$ values) was higher for the $\mathrm{P}_{2}$ and $\mathrm{P}_{3}$ progeny populations compared to the parental population $\mathrm{P}_{0}$ (Table 2); however, in comparison to low-rate selection studies with other herbicides, the level of resistance did not increase substantially.

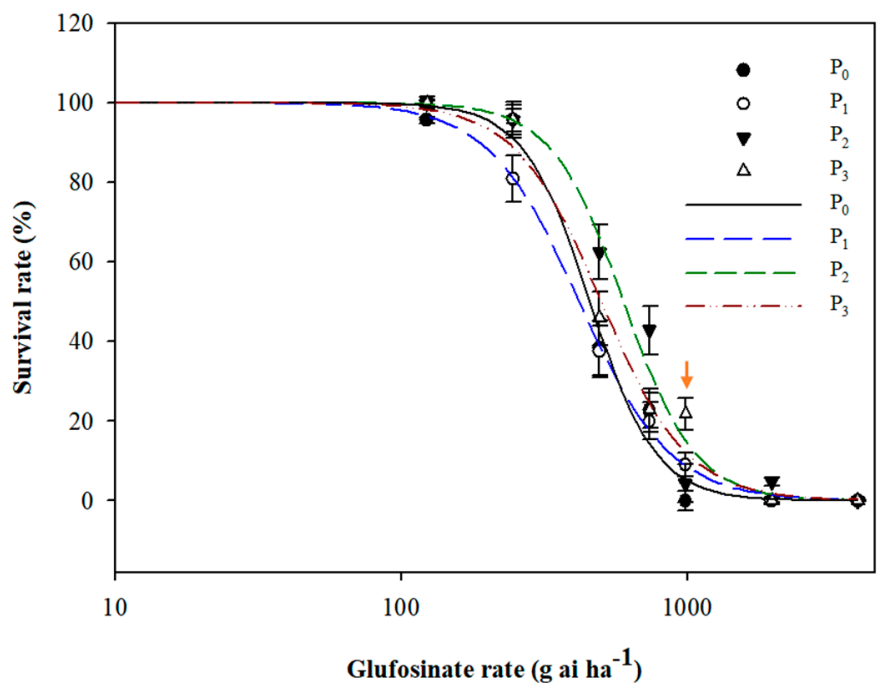

Figure 1. Dose-response of L. perenne ssp. multiflorum parental $\left(\mathrm{P}_{0}\right)$ and three successive generations $\left(\mathrm{P}_{1}\right.$, $\mathrm{P}_{2}, \mathrm{P}_{3}$ ) of progeny, selected with low glufosinate rates, to treatment with glufosinate in the greenhouse. Lines are the predicted values for percentage survival. Red arrow indicates the labelled field rate $\left(984 \mathrm{~g} \cdot \mathrm{ai} \cdot \mathrm{ha}^{-1}\right)$.

Table 2. Parameter estimates and associated model statistics for the log-logistic dose-response curves of plant survival following treatment with glufosinate at low doses.

\begin{tabular}{|c|c|c|c|c|}
\hline Population & ${ }^{a} \operatorname{LD}_{50}\left(\mathrm{~g} \cdot \mathrm{ai} / \mathrm{ae} \cdot \mathrm{ha} \mathrm{a}^{-1}\right)$ & $S E^{d}$ & $\mathrm{RI}^{\mathrm{e}}\left(\mathbf{P}_{\mathrm{n}} / \mathbf{P}_{0}\right)$ & SE RI \\
\hline $\mathrm{P}_{0}$ & $452.39(382.77-522.02)^{\mathrm{c}}$ & 35.52 & - & 0.11 \\
\hline $\mathrm{P}_{1}$ & $429.95(351.98-507.93)$ & 39.78 & 0.95 & 0.11 \\
\hline $\mathrm{P}_{2}$ & $592.08(502.46-681.7)$ & 45.72 & 1.31 & 0.14 \\
\hline \multirow[t]{2}{*}{$\mathrm{P}_{3}$} & $529.2(444.75-613.65)$ & 43.08 & 1.16 & 0.13 \\
\hline & ${ }^{b} L_{90}\left(g \cdot a i / a \cdot h a^{-1}\right)$ & SE & $\operatorname{RI}\left(\mathbf{P}_{n} / \mathbf{P}_{0}\right)$ & SE RI \\
\hline $\mathrm{P}_{0}$ & 817.66 (640.4-994.92) & 90.44 & - & 0.15 \\
\hline $\mathrm{P}_{1}$ & 888.82 (656.12-1121.5) & 118.72 & 1.08 & 0.18 \\
\hline $\mathrm{P}_{2}$ & $1117.58(839.05-1396.1)$ & 142.10 & 1.36 & 0.23 \\
\hline $\mathrm{P}_{3}$ & $1038.16(782.07-1294.3)$ & 130.66 & 1.26 & 0.21 \\
\hline
\end{tabular}

${ }^{a} \mathrm{LD}_{50}$-represents the rate that results in $50 \%$ mortality. ${ }^{\mathrm{b}} \mathrm{LD}_{90}$-represents the rate that results in $90 \%$ mortality. ${ }^{c}$ Values in parentheses indicate $95 \%$ confidence intervals. ${ }^{d} \mathrm{SE}$ - standard error. ${ }^{\mathrm{e}} \mathrm{RI}$, the resistance index, is a population's $\mathrm{LD}_{50}$ or $\mathrm{LD}_{90}$ divided by the value of the same parameter for the parental population, $\mathrm{P}_{0}$. 


\subsection{Cross-Resistance to Glyphosate, Paraquat, and Sethoxydim}

Interestingly, no plants of the parental population or the $\mathrm{P}_{1}, \mathrm{P}_{2}$, and $\mathrm{P}_{3}$ progeny survived glyphosate, paraquat, and sethoxydim treatments equal to and greater than $0.75 \mathrm{X}$ the labelled rates of these herbicides (Figure 2A-C, Table 3). Busi et al. [22] suggested that selection using low rates may hasten the evolution of polygenic herbicide resistance, especially in cross-pollinated species such as L. perenne ssp. multiflorum. The authors suggest that reduced sensitivity to chlorsulfuron was observed in progeny from low-rate diclofop methyl selection, apparently as a result of enhanced detoxification of both herbicides [23]. Cross-resistance to glufosinate and glyphosate was previously suggested in L. perenne from Oregon, and the resistance hypothesized to be non-target-site related [19]. In this study, reduced susceptibility to the 0.5X rate of glyphosate was detected following two and three generations of selection with low rates of glufosinate (Table 3), but further research is required to determine whether this is due to cross-resistance.

(A)

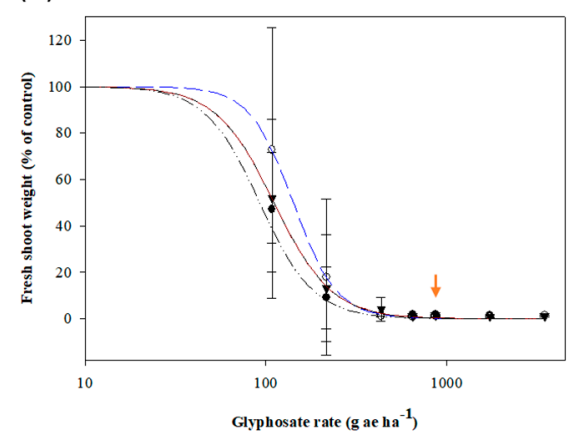

(C)

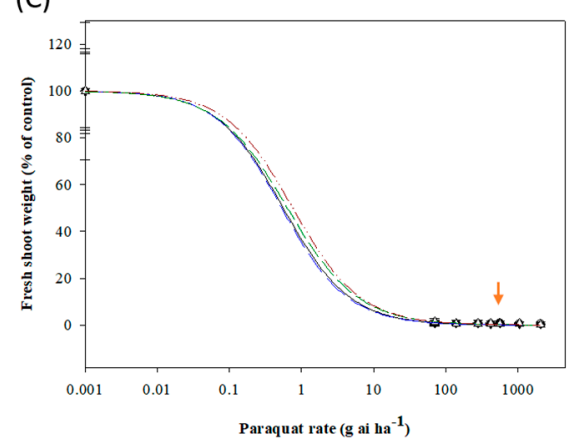

(B)

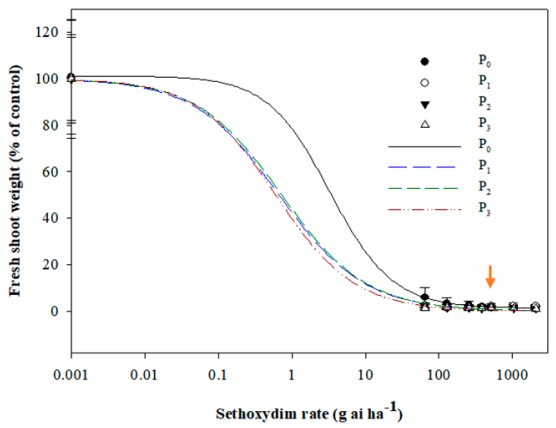

Figure 2. Dose-response of L. perenne ssp. multiflorum parental $\left(\mathrm{P}_{0}\right)$ and three successive generations $\left(\mathrm{P}_{1}\right.$, $\mathrm{P}_{2}, \mathrm{P}_{3}$ ) of progeny, selected with low rates of glufosinate, to treatment with glyphosate $(\mathbf{A})$, sethoxydim (B), and paraquat (C) in the greenhouse. Lines are the predicted values for fresh shoot weight. Red arrows indicate the labelled field rates for glyphosate $\left(867 \mathrm{~g} \cdot \mathrm{ae} \cdot \mathrm{ha}^{-1}\right)$, paraquat $\left(560 \mathrm{~g} \cdot \mathrm{ai} \cdot \mathrm{ha} \mathrm{a}^{-1}\right)$, and sethoxydim (515 g.ai.ha $\left.{ }^{-1}\right)$.

In most recurrent low rate selection studies, resistance level exceeded three-fold after three generations of low-rate selection $[5,7,9,24]$. In this study, the magnitude of increases in resistance levels over three generations of recurrent low-rate glufosinate selection observed contrasted with the higher levels of resistance observed in response to low-rate selection with other herbicides. However, the results are consistent with previous studies of glufosinate resistance in Lolium species, which generally observe lower levels of resistance to glufosinate with $\mathrm{R} / \mathrm{S}$ ratios ranging from 1.6 to 2.8 fold $[13,18,19]$. Our earlier work [14] also found significant variability in response to glufosinate among individuals in California populations of L. perenne ssp. multiflorum and a strong influence of environmental conditions on glufosinate efficacy and sensitivity, which has also been detected in Raphanus raphanistrum [25] and A. rudis, A. palmeri, and A. retroflexus [26]. Whether the evolution of glufosinate resistance in weed populations is more complex than resistance evolution to other 
herbicides remains to be investigated. However, the results of this study provide clear evidence that reduced susceptibility to glufosinate can evolve in weed populations following repeated applications of glufosinate at low herbicide rates.

Table 3. Percentage of plants from the parental population $\left(\mathrm{P}_{0}\right)$ and three generations of progeny $\left(\mathrm{P}_{1}-\mathrm{P}_{3}\right)$ that survived treatment with glyphosate, paraquat, and sethoxydim 21 DAT $^{\mathrm{a}}$.

\begin{tabular}{cccccccccc}
\hline & \multicolumn{1}{c}{ \% Survivors at Each Herbicide Rate } \\
\hline \multirow{3}{*}{ Glyphosate } & Population & $\mathbf{0}$ & $\mathbf{0 . 1 2 5}$ & $\mathbf{0 . 2 5}$ & $\mathbf{0 . 5}$ & $\mathbf{0 . 7 5}$ & $\mathbf{1}$ & $\mathbf{2}$ & $\mathbf{4}$ \\
& $\mathrm{P}_{0}$ & 100 & 100 & 45 & 0 & 0 & 0 & 0 & 0 \\
& $\mathrm{P}_{1}$ & 100 & 100 & 20 & 0 & 0 & 0 & 0 & 0 \\
& $\mathrm{P}_{2}$ & 100 & 100 & 20 & 20 & 0 & 0 & 0 & 0 \\
& $\mathrm{P}_{3}$ & 100 & 80 & 20 & 20 & 0 & 0 & 0 & 0 \\
\hline \multirow{3}{*}{ Paraquat } & $\mathrm{P}_{0}$ & 100 & 0 & 0 & 0 & 0 & 0 & 0 & 0 \\
& $\mathrm{P}_{1}$ & 100 & 10 & 0 & 0 & 0 & 0 & 0 & 0 \\
& $\mathrm{P}_{2}$ & 100 & 0 & 0 & 0 & 0 & 0 & 0 & 0 \\
& $\mathrm{P}_{3}$ & 100 & 20 & 0 & 0 & 0 & 0 & 0 & 0 \\
\hline \multirow{5}{*}{ Sethoxydim } & $\mathrm{P}_{0}$ & 100 & 10 & 10 & 0 & 0 & 0 & 0 & 0 \\
& $\mathrm{P}_{1}$ & 100 & 0 & 0 & 0 & 0 & 0 & 0 & 0 \\
& $\mathrm{P}_{2}$ & 100 & 0 & 0 & 0 & 0 & 0 & 0 & 0 \\
& $P_{3}$ & 100 & 10 & 0 & 0 & 0 & 0 & 0 & 0 \\
\hline
\end{tabular}

In summary, in this study we showed that three generations of recurrent selection with glufosinate at low rates (i.e., lower than the labelled field rates) was sufficient to reduce the susceptibility of subsequent generations $\left(\mathrm{P}_{1}-\mathrm{P}_{3}\right)$ of progeny to the herbicide compared with the parental population $\left(\mathrm{P}_{0}\right)$ (Figure 1). Our findings are consistent with the results of other studies showing that recurrent low-rate selection may lead to the evolution of herbicide resistance $[5,9,22,24]$. Reduced susceptibility to paraquat and sethoxydim with successive generations of glufosinate selection was not observed. The increases in frequency of plants surviving increasing glufosinate rates each successive generation may reflect a shift in mean response at the population level indicative of directional selection on quantitative trait variation and, possibly, non-target site related glufosinate resistance.

Author Contributions: M.J. conceived the study; M.M. and S.M. conducted the experiments, S.M. conducted the statistical analyses; M.M., and M.J. wrote the manuscript with contributions from S.M. All authors have read and agreed to the published version of the manuscript.

Funding: This study was funded by Bayer CropScience AG and by BASF Corporation, and M.J. was supported by USDA National Institute of Food and Agriculture Hatch Project 1002110.

Acknowledgments: We are grateful to Chad Fautt for greenhouse and laboratory assistance, and to Hannah Clifton for greenhouse maintenance.

Conflicts of Interest: The authors declare no conflict of interest.

\section{References}

1. Oerke, E.C. Crop losses to pests. J. Agric. Sci. 2006, 144, 31-43. [CrossRef]

2. Powles, S.B.; Yu, Q. Evolution in action: Plants resistant to herbicides. Annu. Rev. Plant Biol. 2010, 61, 317-347. [CrossRef]

3. Délye, C.; Jasieniuk, M.; Le Corre, V. Deciphering the evolution of herbicide resistance in weeds. Trends Genet. 2013, 29, 649-658. [CrossRef] [PubMed]

4. Gressel, J. Low pesticide rates may hasten the evolution of resistance by increasing mutation frequencies. Pest Manag. Sci. 2011, 67, 253-257. [CrossRef] [PubMed]

5. Tehranchian, P.; Norsworthy, J.K.; Powles, S.; Bararpour, M.T.; Bagavathiannan, M.V.; Barber, T.; Scott, R.C. Recurrent sublethal-dose selection for reduced susceptibility of palmer amaranth (Amaranthus palmeri) to dicamba. Weed Sci. 2017, 65, 206-212. [CrossRef] 
6. Norsworthy, J.K. Repeated sublethal rates of glyphosate lead to decreased sensitivity in palmer amaranth. Crop Manag. 2012, 11, 1-6. [CrossRef]

7. Neve, P.; Powles, S. Recurrent selection with reduced herbicide rates results in the rapid evolution of herbicide resistance in Lolium rigidum. Theor. Appl. Genet. 2005, 110, 1154-1166. [CrossRef]

8. Busi, R.; Gaines, T.A.; Walsh, M.J.; Powles, S.B. Understanding the potential for resistance evolution to the new herbicide pyroxasulfone: Field selection at high doses versus recurrent selection at low doses. Weed Res. 2012, 52, 489-499. [CrossRef]

9. Busi, R.; Girotto, M.; Powles, S.B. Response to low-dose herbicide selection in self-pollinated Avena Fatua. Pest Manag. Sci. 2016, 72, 603-608. [CrossRef]

10. DiTomaso, J.M.; Healy, E.A. Weeds of California and other Western States. In California Division of Agriculture and Natural Resources; University of California Division of Agriculture and Natural Resources publication: Oakland, CA, USA, 2007; Volume 2, pp. 1195-1200. ISBN 1879906694.

11. Jasieniuk, M.; Ahmad, R.; Sherwood, A.M.; Firestone, J.L.; Perez-Jones, A.; Lanini, W.T.; Mallory-Smith, C.; Stednick, Z. Glyphosate-resistant Italian ryegrass (Lolium multiflorum) in California: Distribution, response to glyphosate, and molecular evidence for an altered target enzyme. Weed Sci. 2008, 56, 496-502. [CrossRef]

12. Brunharo, C.A.C.G.; Hanson, B.D. Vacuolar sequestration of paraquat is involved in the resistance mechanism in Lolium perenne L. spp. multiflorum. Front. Plant Sci. 2017, 8, 1485. [CrossRef] [PubMed]

13. Karn, E.; Beffa, R.; Jasieniuk, M. Variation in response and resistance to glyphosate and glufosinate in California populations of Italian ryegrass (Lolium perenne ssp. multiflorum). Weed Sci. 2018, 66, 168-179. [CrossRef]

14. Tehranchian, P.; Nandula, V.; Jugulam, M.; Putta, K.; Jasieniuk, M. Multiple resistance to glyphosate, paraquat and ACCase-inhibiting herbicides in Italian ryegrass populations from California: Confirmation and mechanisms of resistance Parsa Tehranchian. Pest Manag. Sci. 2018, 74, 868-877. [CrossRef] [PubMed]

15. Tehranchian, P.; Nandula, V.K.; Matzrafi, M.; Jasieniuk, M. Multiple herbicide resistance in California Italian ryegrass (Lolium perenne ssp. multiflorum): Characterization of ALS-inhibiting herbicide resistance. Weed Sci. 2019, 67, 273-280. [CrossRef]

16. Simarmata, M.; Kaufmann, J.E.; Penner, D. Potential basis of glyphosate resistance in California rigid ryegrass (Lolium rigidum). Weed Sci. 2003, 51, 678-682. [CrossRef]

17. Heap, I. The International Survey of Herbicide Resistant Weeds. Available online: http://www.weedscience. com (accessed on 5 July 2020).

18. Avila-Garcia, W.V.; Sanchez-Olguin, E.; Hulting, A.G.; Mallory-Smith, C. Target-site mutation associated with glufosinate resistance in Italian ryegrass (Lolium perenne L. ssp. multiflorum). Pest Manag. Sci. 2012, 68, 1248-1254. [CrossRef]

19. Avila-Garcia, W.V.; Mallory-Smith, C. Glyphosate-resistant Italian ryegrass (Lolium perenne) populations also exhibit resistance to glufosinate. Weed Sci. 2011, 59, 305-309. [CrossRef]

20. Development Core Team [R 2010]. R: A Language and Environment for Statistical Computing; R Foundation for Statistical Computing: Vienna, Austria; ISBN 3-900051-07-0. Available online: http://www.R-project.org (accessed on 2 July 2020).

21. Seefeldt, S.S.; Jensen, J.E.; Fuerst, E.P. Feature log-logistic analysis of herbicide dose-response relationships. Weed Technol. 1995, 9, 218-227. [CrossRef]

22. Busi, R.; Neve, P.; Powles, S. Evolved polygenic herbicide resistance in Lolium rigidum by low-dose herbicide selection within standing genetic variation. Evol. Appl. 2013, 6, 231-242. [CrossRef]

23. Yu, Q.; Han, H.; Cawthray, G.R.; Wang, S.F.; Powles, S.B. Enhanced rates of herbicide metabolism in low herbicide-dose selected resistant Lolium rigidum. Plant. Cell Environ. 2013, 36, 818-827. [CrossRef]

24. Ashworth, M.B.; Walsh, M.J.; Flower, K.C.; Powles, S.B. Recurrent selection with reduced 2,4-D amine doses results in the rapid evolution of 2,4-D herbicide resistance in wild radish (Raphanus raphanistrum L.). Pest Manag. Sci. 2016, 72, 2091-2098. [CrossRef] [PubMed] 
25. Kumaratilake, A.R.; Preston, C. Low temperature reduces glufosinate activity and translocation in wild radish (Raphanus raphanistrum). Weed Sci. 2005, 53, 10-16. [CrossRef]

26. Coetzer, E.; Al-Khatib, K.; Loughin, T.M. Glufosinate efficacy, absorption, and translocation in amaranth as affected by relative humidity and temperature. Weed Sci. 2001, 49, 8-13. [CrossRef]

(C) 2020 by the authors. Licensee MDPI, Basel, Switzerland. This article is an open access article distributed under the terms and conditions of the Creative Commons Attribution (CC BY) license (http://creativecommons.org/licenses/by/4.0/). 